\title{
Effect of Some Environmental Factors on the Predation Efficiency of the Mosquito; Toxorhynchites splendens (Diptera: Culicidae)
}

\author{
Hanaa I. Mahmoud \\ Zoology Department, Faculty of Science (Girls), Al-Azhar University, Cairo, Egypt.
}

\begin{abstract}
The present work investigates the optimum conditions for the application of the predaceous mosquito, Toxorhynchites splendens as a biological control agent for other vector mosquito species in Egypt such as, Culex pipiens, Anopheles pharoensis and Aedes caspius under field conditions.

The predation efficiency of $T$. splendens larvae was found to increase as the temperature increased. At 30-35:C the predaceous larvae consumed greater numbers of both C. pipiens and Ae. Caspius than that of A. pharoensis. The predation of T. splen dens occurred almost similarly in all degree of salinity. On the other hand, light was found to have little effect on Toxorhynchites larvae where predation efficiency was decreased in the dark. The crowding had no effect on the predation. Also no mortality or natural diseases were observed among the tested insect larvae during the experim ental period, whereas the insect preferred to live in highly concentrated population.

Toxorhynchites splendens larvae could live in turbid and distilled water. The maximum number of prey larvae consumed by all instars of T. splendens was at PH (8) followed by (7) and (9). However, $\mathrm{pH}$, below (6) and above 11 had a bad effect on the predaceous activity. The predation efficiency of $T$. splendens larvae increased gradually as the depth of water decreased .However captures of prey occurred either on the surface or at the bottom of the container.
\end{abstract}

\section{Introduction}

Although insecticides continue to play a significant role in the control of mosquitoes involved in disease trans -mission, biological control of mosquito with predatory organisms in most instan -ces is more acceptable from an enviro nmental stand point and has been appl ied in many situations with reason -able success (WHO, 1995).

Biological control with indige nous predators/parasites may be more available, comparatively less expensive, and more compatible with the economic realities of many countries of sub-Saha -ran Africa. Predatory organisms are particularly suitable for control of aquatic stages of mosquitoes. Among the organisms most extensively studied in this regard are the larvae of the mosquito, Toxorhynchites splendens ( Mkoji et al., 1999). This species is considered to be one of the most useful agents for the biological control of other vector and nuisance mosquitoes (Cheo ng and Ganapathipillai, 1964, Chan 1968; Yasuno and Tonn, 1970) and also for aedine vector of various diseases such as filariasis, dengue and yellow fever (Horio et al., 1990).

Recently, T. splendens mosq uito has been also recognized for use in the isolation of arboviruses and filariae. 
Advantages of Toxorhynchites adults lie in their safety (nonbiting) and large size (Eshita et al., 1982).

Unlike many other insect preda tors T.splendens can not search for a suitable prey patch, but is committed for pre adult life to the oviposition site of the female (Lounibos 1979). The depth preference for the oviposition site of Toxorhynchites species need to be inves -tigated in both laboratory and field. Successful biological control prog rams requires finding the proper match betw -een the preferred oviposition sites of the most suitable species of Toxorhynchites and the intended mosquito prey.

The capacity of Toxorhynchities larvae as a predators on some mosquito species larvae had been observed by a number of authors ( e.g. Paiva ,1910; Jenkins, 1964; Focks, 1985; Annis et al. 1989 and Rawlins et al.1991).

The present study was carried out to determine the effect of some envi -ronmental factors on the predation effi -ciency of $T$. splendens larvae on $C$.pip -ens, Ae. caspius and A. pharoensis larvae .

\section{Materials and Methods \\ Maintenance of mosquitoes} a-Toxorhynchites splendens :

Immature and adult mosquitoes were maintained under insectary cond itions of $26 \pm 1^{\circ} \mathrm{C}$ temperature, $75 \pm 5 \%$ $\mathrm{RH}$ and light : dark regime of $14: 10 \mathrm{~h}$ at the department of Zoology, Faculty of Science (for girls), Al-Azhar University. About 50 adults were kept in each cage $(20 \times 20 \times 30 \mathrm{~cm})$ with a stainless wire frame enclosed with white nylon mesh with a sleeve at a lateral end. Adults were fed on an $8 \%$ sucrose solution in a 150-ml Ehrlemeyer flask with a cellu -lose wick. For oviposition a black plas -tic cup containing distilled water was provided. For crossing experiments, larv -ae were reared individually in $100 \mathrm{ml}$. plastic vials each containing $50 \mathrm{ml}$. of distilled water. For routine maintenance, however, larvae were reared in masses in plastic tray $(20 \times 30$ x $6.5 \mathrm{~cm}$ ) containing 2 liters of distilled water. They were fed on larvae of Aedes aegy - pti (Linn) with a prey/predator ratio of 15:1. Pupae were sexed and placed individually into small capsules.

\section{b-Culex pipiens, Anopheles pharoensis} and Aedes caspuis

Colonies of Anopheles pharoensis, Culex pipiens and Aedes caspius were raised in the laboratory. The insects were obtained as larvae or pupae from Ain Shams University and Faiyum governorate. The cultures of these insect species were reared in the laboratory as described by Geberg (1970).

\section{Number of prey larvae consumed by Toxorhynchites splendens larvae.}

A colony of $T$. splendens was maintained as described before. Eggs for experimentation were removed from the container in the colony cages as soon as possible after oviposition and placed in separate vials $(2 \times 3 \mathrm{~cm})$ containing distilled water. All materials was kept at $30^{\circ} \mathrm{C} \pm 1$ and monitored for eclosion. Prey consumption were coun -ted in all instars. Each freshly hatched T. splendens larvae were offered $1001^{\text {st }}$ instar C. pipiens, Ae. Caspinus and A. pharoensis larvae as prey separately before the head capsule hardened. When the $1^{\text {st }}$ moult occurred, the Toxorhyn chites larvae were transferred to clean vials and the remaining prey were counted. The procedure was repeated supplying the newly moulted $2^{\text {nd }}$ instar Toxorhynchites with $1002^{\text {nd }}$ instar $C$. pipiens, A. pharoensis and Ae caspius (each in a separate vial). When the Toxorhynchites larvae moulted to the $3^{\text {rd }}$ 
instar, they were transferred to larger jars $(5 \times 7 \mathrm{~cm})$ and offered 100 third instar $C$. pipiens, A. pharoensis and Ae. caspius daily until pupation occurred. All jars were cleaned every $24 \mathrm{hrs}$ to minimize microbial contamination.

Five replicates of hundred indivi -duals were used. The vials were exam ined daily and the number of prey consu -med by $T$. splendens larvae were calculated.

\section{Effect of certain factors affecting the predation efficiency:}

I- Temperature :

The predation efficiency of T.splendens was tested under different temperature degrees. Seven temperature degrees were tested ranging between $15^{\circ} \mathrm{C}$ up to $45^{\circ} \mathrm{C}$. Temperature degrees below and above this range level was found to have an undesirable effect on the activity of the insects. The tested larvae were reared in the laboratory at $30^{\circ} \mathrm{C} \pm 1$ in distilled water.

Groups of thirty to fifty larvae were used in these experiments and were divided into 5 replicates, at each temperature degree. The predation effic -iency of T.splendens from $1^{\text {st }}$ instars to $4^{\text {th }}$ instars was determined. The tested larvae were incubated at $45,{ }^{\circ} \mathrm{C}, 40^{\circ} \mathrm{C}$, $35^{\circ} \mathrm{C}, 30^{\circ} \mathrm{C}, 25^{\circ} \mathrm{C}, 20^{\circ} \mathrm{C}$ and $15^{\circ} \mathrm{C} \pm 1$. Examination for larval preda -tion were continued daily for 3 days.

\section{II - Salinity}

In order to trace the effect of different salinity degrees on the preda tion of $T$. splendens larval instars they were tested against, Ae. caspius, $C$. pipiens, and $A$. pharoensis at salinity degrees of $0.39 \%, 0.12 \%, 0.16 \%$ and $0.675 \%$.

This salinity was prepared acco rding to a procedure suggested by Ward (1962). Fifty larvae from each instar in two replicates were tested at each salinity. The larvae were put in plastic boxes filled with water of different salinities. The numbers of prey larvae consumed from the three mosquitoes species at the different salinities were calculated.

\section{III- Dark and light}

In order to evaluate the response and the predation efficiency of $T$. splen -dens larvae under daylight and comp lete darkness, fifty $1^{\text {st }}$ insatr larvae of $T$. splendens were divided into two groups with Culex larvae as host. In the $1^{\text {st }}$ group, the larvae were transferred into transparent plastic boxes. These boxes were exposed to diffused sunlight in the laboratory. Larvae in the second group were kept in the same plastic boxes but incubated inside a tight wooden cage which didn't permit any day light. Num -bers of Culex larvae consumed were recorded in each group. The expe riments were carried out using the $1^{\text {st }}$, $2^{\text {nd }}, 3^{\text {rd }}$ and $4^{\text {th }}$, instar larvae. The number of prey larvae consumed by $T$. splendens was calculated. Also, $50 \mathrm{~T}$. splendens larvae (in two groups) from each of $1^{\text {st }}, 2^{\text {nd }}, 3^{\text {rd }}$ and $4^{\text {th }}$ instars were tested against Ae.caspius and A.phar oensis larvae.

\section{IV- Crowding :}

To detect the effect of crowding on the predation of Toxorhynchites larv -ae, the fourth instar larvae were transf erred to plastic boxes. The larvae were divided into groups of different numb ers ranging from one to twenty in each. Five replicates for each group was tested. Larvae were given different num -bers of their prey mosquito larvae from C.pipiens, A.pharoensis, and Ae.ca -spius. The number of consumed larvae were counted in each group.

V-Water-type preference

These experiments were carried out to investigate the preferred type of 


\section{Hanaa I.Mahmoud}

water for the predation of $T$. splendens larvae on the other mosquito larvae tested.

Eggs were removed from the container in the colony cage as soon as possible after oviposition and placed in separated vials ( $2 \times 3 \mathrm{~cm}$ ) containing distilled water. Another vials containing polluted water (Sewage) and turbid water with some of the eggs were test ed. All materials were kept at $30^{\circ} \mathrm{C} \pm 1$ and monitored for eclosion. The Fre shly hatched T.splendens larvae were offered hundred $1^{\text {st }}$ instar C.pipines as a prey in 3 vials. The 3 vials with the different types of water were examined daily and the number of prey consumed by $T$. splendens were calculated. The same experiment were carried out using the $2^{\text {nd }}, 3^{\text {rd }}$, and $4^{\text {th }}$ instar larvae against A.caspius, and A.pharoensis larvae. Five replicate were tested for each instar.

\section{VI- Water PH :}

In order to trace the effect of different water $\mathrm{PH}$ on the predation of out to investigate the preferred type of Toxorhynchites larval instars against tested Ae.caspius, C.pipiens and A.phar -oensis larvae. 4,5,6,7,8,9,10,11PH we re used. These $\mathrm{PH}$ were prepared by potentiometric instrument. The range of tested $\mathrm{PH}$ almost brackts the $\mathrm{PH}$ in the field and that of the tap water. Fifty larvae from each instar of $T$. splendens were tested in five replicates at each $\mathrm{PH}$. The larvae were put in plastic boxes filled with water of different $\mathrm{PH}$, and provided with their host. The number of prey larvae consumed from the three mosquito species at different $\mathrm{PH}$ were recorded.

VII- Water depth:

The effect of water depth on the predation of $T$. splendens larval instars were tested.
The first instar larvae were put in 3 plastic boxes filled with water of different depths 40, 20 and $15 \mathrm{~cm}$. Fifty larvae were used in five replicates for each depth. The same experiments were carried out on the $2^{\text {nd }}, 3^{\text {rd }}$ and $4^{\text {th }}$ instar larvae. The number of prey larvae consu -med by all instars and at different depth were calculated.

\section{Results and Discussion}

Number of prey larvae consumed by Toxorhynchites splendens larvae:

These experiments were carried out to test the number of prey larvae consumed by Toxorhynchites splendens from the three mosquito species Culex pipiens, Anopheles pharoensis and Aed - es caspius. To confirm the results obtai -ned from the experiments, they were repeated 3 times. Results obtained on the response of Toxorhynchites splen dens to the 3 species of mosquitoes are presented in the (Table, 1).

The data in table (1), show that the average number of preys consumed the $1^{\text {st }}$ larval instar of Toxorhynchites splendens from their prey Culex pipiens, Anopheles pharoensis and

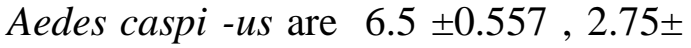
0.5 and $4.5 \pm 0.33$ larvae per larva respectively. In case of the $2^{\text {nd }}$ instar larvae, the number of prey consumed are $9.5 \pm, 0.577,3.5 \pm 0.57$ and $9 \pm 1.154$ larvae per larva respectively. Also, it is clear that the number of prey larvae consumed by the $3^{\text {rd }}$ and $4^{\text {th }}$ instars were $8.25 \pm 0.957,3.75 \pm 0.5$ and $9 \pm 1.154$ in case of the former; $6.5 \pm 0.577,2.5 \pm$ 0.57 and $5.5 \pm 1.29$ respectively in case of the latter instar larvae.

From these data it is clear that Toxorh ynchites splendens larvae respo -nded similarly to Culex pipiens and Aedes caspius larvae. The feeding capacity of the $2^{\text {nd }}$ and $3^{\text {rd }}$ instar is greater than that in the $1^{\text {st }}$ and $4^{\text {th }}$ larval instar. From the 

statistical analysis of the data, it is clear that: (i) There are significant differences between the number of both Culex pipi ens and Aedes caspius larvae and those of Anopheles pharoensis consumed by Toxorhynchites splendens lar -vae in all instars. (ii) There is no significant difference between the number of Culex pipiens larvae and those of Aedes casp ius consumed by Toxorhynchites splen dens larvae.

The effect of different tempe rature degrees on the predation efficie ncy of $T$. splendens larvae is shown in Table (2), the results indicated that the predation efficiency of T.splendens larvae was increased as the temperature increased, where more prey of C.pipi ens and Ae.caspius were consumed at degree from $30-35^{\circ} \mathrm{C}$ than that of A.pharoensis.

The analysis of the data (Table 2) showed that, in case of the $1^{\text {st }}$ insatr, there were significant differences between the number of prey larvae of C.pipiens, A.pharoensis and A.caspius consumed by Toxorhynchites larvae incubated at $30^{\circ} \mathrm{C} \pm 1$ and those incubated at $15,20,40$ and $45^{\circ} \mathrm{C}$.

In case of the $2^{\text {nd }}, 3^{\text {rd }}$ and $4^{\text {th }}$ instars, there were significant differe nces between the number of prey larvae consumed by Toxorhynchites larvae inc -ubated at $30^{\circ} \mathrm{C} \pm 1$ and those incubated at $15,20,25,40$ and $45^{\circ} \mathrm{C}$. At $30 \mathrm{C}$. there were significant differences between the unmber of both $\mathrm{C}$. pipiens and Ae. Caspius larvae consumed by Toxorhy nchites larvae and those of $A$.. pharoensis larvae. Also the results showed that at the degrees from 30$35^{\circ} \mathrm{C}$ the predator larvae consumed greater numbers of both $C$. pipiens, Ae. caspius than that of $A$. pharoensis. These results agree with the findings of Trips (1972) who tested the effect of temperature on the predation of Toxorhy -nchites brevipalpis. this data indicated that predation in $T$. brevipalpis larvae was greater at high temperature degrees with more prey was consumed at 30- $35^{\circ} \mathrm{C}$ than at $20-25^{\circ} \mathrm{C}$. It may be pointed out that the temperature surrou nding the larvae affect their feeding capacity.

The data shown in Table (3) represent the effect of salinity on the predation efficiency of T.splendens larvae. The response of the insect larvae in all salinities studied are nearly equal in their predation to C.pipiens and Ae. caspius. Also it was clear that the number of Anopheles larvae consumed by all instars of Toxorhynchites larvae was less than in case of the former two mosquito species. Moreover the data (Table 3) indicated that (i) In all instars there was significant difference between the number of prey larvae (C.pipiens, $A$. pharoensis and Ae.caspius) consumed by Toxorhynchites larvae reared in water at salinity of $0.16 \%$ and those reared in water at the salinity of $0.39 \%$ except that in case of the $3^{\text {rd }}$ instar. There was no significant difference between the number of Anopheles lar vae consumed by Toxorhynchites larv ae at the salinity of $0.16 \%$ and those at $0.675 \%$.

(ii) There was no significant difference between the number of prey larvae $(C$. pipiens, A. pharoensis and Ae. caspius) consumed by $1^{\text {st }}, 2^{\text {nd }}, 3^{\text {rd }}$ and $4^{\text {th }}$ instars of $T$. splendens reared in water at a salinity of 0.16 and those at the salinity 0.12 .

(iii) In all instars, there was a significant difference between the number of host larvae (C. pipiens, A. pharoenies and Ae. caspius) consumed by Toxorhynchites larvae reared in water at the salinity $0.16 \%$ and those reared at $0.675 \%$ except in case of the $2^{\text {nd }}$ and $3^{\text {rd }}$ instars where there was no significant difference between the number of Ae.caspius larvae consumed by Toxorhynchites larvae.

(iv) There was a significant difference between the number of larvae consumed from C. pipiens, Ae. caspius, and those 


\section{Hanaa I.Mahmoud}

consumed from $A$. pharoensis in all salinities.

These results agree well with that obtained by Richards (1938) who found that Ae. stimulans (Walker) and Ae. wexans (Meigen), (the two flood water mosquitoes usually found in water low in salts) respond differently when reared in a graded series of saline solution. But Kardatzk \& Lien (1972) reported that the two coexisting mosquitoes $A e$. vexans and Ae. stimulans have different abilities to tolerate varied salinities, where Ae. vexans larvae were able to tolerate higher saline conditions than those of Ae. stimulans.

Results in Table (4) revealed that light seemed to have little effect on Toxorhynchites larvae but it increased predation than that in the dark due to the greater activity of the prey in the light.

Also the results cleared that the response of all larval instar of $T$. splendens to their host $C$. pipiens and Ae. caspius in both light and dark was nearly equal. It was $6.5 \pm 0.5,8.75 \pm 0.5$, $8.75 \pm 0.5, \& 5.5 \pm 0.57$ and $4.5 \pm 0.57$, $8.75 \pm 0.5,8.78 \pm 0.5 \& 5.5 \pm 0.5$ prey for $1^{\text {st }}, 2^{\text {nd }}, 3^{\text {rd }}$ and $4^{\text {th }}$ instars, respectively.

The number of Anopheles larvae cons -umed by the Toxorhynchites larvae in both dark and light was decrease it was $1.5 \pm 0.57,1.5 \pm 0.5,2.75 \pm 0.5 \& 3.25 \pm 0.5$ and $2.5 \pm 0.57,3.75 \pm 0.5,3.75 \pm 0.577$ $\& 4.5 \pm 0.54$ prey in case of $1^{\text {st }}, 2^{\text {nd }}, 3^{\text {rd }}$ and $4^{\text {th }}$ instars, respectively. So, light is one of the important ecological factors that affect predation.

The statistical analyses of the Table (4) cleared that in general there are significant differences between the number of host larvae $C$. pipiens, $A$. pharoensis and those of Ae. caspius, consumed by all instars of $T$. splendens larvae which kept in light and those kept in dark. These finding support those obtained by Goma (1964) who reported that light seemed to has a little effect on predation of $T$. brevipalpis condradi, but it greatly increased predation in $T$. raimosi larvae.

The results of the crowding experiment (table 5) revealed that in all groups used the crowding had no effect on the predation. Also no mortality or natural diseases were observed among the tested insects larvae during the experimental periods. This phenomenon may be return to that these insect larvae prefer always to live in highly concentrated population, which doesn't permit any pathological effects and doesn't affect their predation.

These results are on contrarily with some others as those of Terzian and Stahler (1949) who found that in the case of mosquito larvae living in over crowding condition generally resu -lted in retarted growth, high mortality among the small larvae, adults of nonuniform size and a decreased fecundity. Meanwhile Andrewartha and Birch (1954) reported that over crowding of organisms produced adverse effects on their survival, rate of development, and population growth. These findings contr -adict with the present results, since the crowding has no effect on the predation efficiency of $T$. splendens larvae. Also no mortality or natural diseases was observed amon the tested insects larvae during the experimental periods.

The results of water type preference of $T$. splendens larvae are presented in Table (6). From these data it is clear that Toxorhynchites larvae and their prey could not be live in the polluted water.The data indicated that the average number of prey ( $C$. pipiens, $A$. pharoensis and Ae. caspius) consumed by the $1^{\text {st }}$ instar was $6.5+0.57,3.25 \pm 0.5$, and $5.5 \pm 0.57$ prey in distilled water and $4.5 \pm 0.57,1.5 \pm 0.5$ and $6.5 \pm 0.57$ prey in turbid water for the $2^{\text {nd }}$ instar . Meanwhile, this average was $8.75 \pm 0.5$, $4.7 \pm 0.5,8.75 \pm 0.5$ prey and $9 \pm 1.154$ 
prey and $3.25 \pm 0.5$ and $7.78 \pm 0.5$ prey for the $3^{\text {rd }}$ instar in distilled and turbid water, respectively. Also the data revealed that the $4^{\text {th }}$ instar consumed $6.5 \pm 0.57,3.5 \pm 0.57$ and $5.5 \pm 0.57$ larvae from C. pipiens, A. pharoensis, Ae. caspius in distilled water and 5.5 \pm 0.57 , $3.25 \pm 0.5$ and $6.5 \pm 0.57$ in turbid water respectively.

From the statistical analysis of the data ( table 6) it is clear that: (i) There are no significant differences between the number of prey larvae (from C. pipiens, A. pharoensis and Ae. caspius) lived in distilled water and those lived in turbid water which consumed by the $2^{\text {nd }}$ and $3^{\text {rd }}$ Toxorhynchites larvae.

(ii) There are no significant differences between the number of prey larvae Toxorhynchites larvae.

(ii) There are no significant differences between the number of prey larvae $(C$. pipiens, Ae. caspius) lived in distilled water and consumed by $1^{\text {st }}$ and $4^{\text {th }}$ Toxorhynchites larvae and those lived in turbid water. But in case of Anopheles host. There are significant differences between these lived in distilled water and those lived in turbid water which consumed by $1^{\text {st }}$ or $4^{\text {th }}$ Toxorhynchites larvae. These findings support those reached by Jenkins (1946) who found that the larvae of $T$. rutilus septentr ionalis died when placed in sewage contaminated water or tap water containing approximately 0.3 PPM of chlorine. These results confirm that the insect larvae respond differently to the same host at different type of water.

The effect of $\mathrm{PH}$ on the predation efficiency of Toxorhynchites larvae is shown in table (7). The results indicated that PH below 6 and above 11 had bad effect on the activity of the $1^{\text {st }}$ instar larvae hence these tests were excluded. Also the results cleared that the number of consumed larvae at the same PH by $2^{\text {nd }}, 3^{\text {rd }}$ and $4^{\text {th }}$ instars were fewer in number than at any of the other PH. It is clearly indicated that the maximum number of prey larvae consumed by all instars of Toxorhynchites larvae was at PH8 then followed by the PH7 and 9 where the number of consumed larvae were nearly the same .At the PH6 as well as PH10, the Toxorhynchites larvae showed a bad appetite where they cons -umed few number of their prey. So the insect larvae responded differently to the same host at different $\mathrm{PH}$.

The statistical analysis of the data ( table 7 ) indicated there was highly significant difference between the number of prey larvae, from C. pipiens, A. pharoensis and Ae. caspius, consumed by $2^{\text {nd }}, 3^{\text {rd }}$ and 4 instars of Toxorhynchites larvae which lived at PH8 and those placed at PH (4,5 and 11).Also there was highly significant difference between the number $C$. pipiens ,A. pharoensis and Ae. caspius larvae consumed by $1^{\text {st }} 2^{\text {nd }} 3^{\text {rd }}$ and $4^{\text {th }}$ instars of Toxorhynchites larvae which lived at PH8 and those lived at PH ( 6, 7,9 and 10 ). It was seemed that the insect larvae responded differently to the same host at different PH. These results are in agreement with that found by Laird (1947).

The effect of water depth on the ability of Toxorhynchites to prey is shown in table (8) The data indicated that predation increased as the depth decreased. Also the predator larvae consumed more larvae in case of the $C$. pipiens, Ae. caspius in all instars than in case of $A$. pharoensis larvae. The statistical analysis of data ( table 8 ) indicated no significant differences between the number of consumed larvae from $C$. pipiens, A. pharoensis and Ae. caspius, by 2 nd, 3 rd and 4 th instars of Toxorhynchites larvae at the of depth $15 \mathrm{~cm}$ and $20 \mathrm{~cm}$, but there was a significant difference between the 
number of consumed hosts of these two depth and the depth of $40 \mathrm{~cm}$ in case of the same three instars. In case of $1^{\text {st }}$ Toxorhynchites larval instar there was significant difference between the number of consumed larval host at the three depth used. The results are in agreement with that obtained by Breland (1949), Furumizo et al(1978) and Crans and Staff (1977), using T.rutilus Septentrionalis, where the subsurface predation appeared to be more common.

The present results may be recommended as a useful control meas ure for mosquitoes.

\section{Reference}

1. Andrewartha , H.G. and Birch, L.C. (1954):The distribution and abundance of animals. Univ. Chicago press, Chicago 782p

2. Annis, B.S.; krisnowardajo, S.; Atmosoedjono and Supardi P. (1989):Suppression of larval Aedes aegypti populations. In household water storage containers in Jakarta, Indonesia, through releases of first instars Toxorhynchites splendens larvae. J. AM. Mosq. Control Assoc. 5: $235-238$

3. Breland, O. P. ( 1949): The biol -ogy and the immature stages of the mosquito, Megarhinus septentri -onalis Dyar and Knab. Ann. Entomol. Soc. Am. 42:38-47.

4. Chan, K.L. (1968): Observation on Toxorhynchites splendens (weide -man) in Singapore.Mosq. News. 28:91 -95.

5. Cheong , W.H., and Ganapathipillai , A. (1964): Preliminary observation on the aquatic stages of Toxorh -ynchites in Malaya. Med. J. Malaya 19:58.

6. Crans, W.J. and staff. M.E. (1977): Growth and behavior of colonized Toxorhynchites rutilus eptentrionalis. Mosq. News. 37: 207-211.

7. Eshita , Y.; Kurihara, T. ; Ogawa, T. and Oya, A. (1982): Studies on the susceptibility of mosquito dengue virus.II) improved methods for the laboratory rearing on Toxorhynchites amboinesis (Doles -chall), as laboratory hosts of the virus, JPn. J.Sanit - Zool . 33: 65-70

8. Focks, D.A. (1985): Toxorhy -nchites .pp. 42.45 in: H.C Chapman (ed.), biological control of mosq uitoes. J. Am. Mosq. Cont rol Assoc. Bull.6

9. Furumizo, R.T. and Rundnick, A. (1978): laboratory studies Toxorhynchites splendens Biological observation . Ann. Entomol .Soc. Am . 71:670-673.

10. Geberg, E.J. (1970): Manual for mosquito rearing and experimental techniques. Bull. Am. Mosq. Control Assoc. 5. 1-109

11. Goma, L.K.H. (1964): laboratory observation on the habits of Toxorhynchites lavae. Ann. Trop. Med. Parasital . 58:350-54.

12. Horio, M. and Tsukamoto, M. (1985): Successful laboratory, colonization of Japanese species of Toxorhynchites mosquitoes. Jpn .J.Sanit .Zool. 36: 87-93.

13. Horio, M. ;Tsukamoto, M. and lchiro, M. (1990): Anew mutant, white larvae of the mosquito Toxorhynchites splendens: genetics and cannibalism. J . Am. Mosq. Control Asso. Vol. 6 no.3: 441-445

14. Jenkins, D.W. and Carpenter, S. J. (1946): Ecology of the treehole breeding mosquitoes of nearetic North America. Eol Monoger. 16: 31-47.

15. Jenkins, D.W. (1964): Pathogen, parasites and predators of medically important arthropods 


\section{Effect of Some Environmental Factors}

(Annotated list and bibiorgraphy). Bull . WHO. 30:1-150 (suppl).

16. Kardatzke, J. I. and Khian, k. L. (1972): Growth of Aedes stimulans and $A$. vexans (Diptera: Culicidae) in saline solution. Ann. Entomol .Soc. Am, Vol.65, no.6.

17. Laird, M. ( 1947 ): Some natural enemies of mosquitoes in the vicinity of pal mol mal, New Britain . Trans. K. Soc. N. Z. 76: 453-76.

18. Lounibos, L.P. (1979): Temporal and spatial distribution growth and predatory behavior of Toxorhy -nchites brevipalpis on the Kenya coast. J. Anim .Ecol. 48:21336.

19. Mkoji, G.M; Boyce, T.G.; Boyce, T.G.; Mungi, B.N ;Copeland, R.S; Hofkin, B.V. and Loker, E.S. (1999): predation of aquatic stages of Anopheles gom biae by the Louisiana red swamp crawfish. J.Am. Mosq Control Assoc., 15(1): 69-71

20. Paiva, G.A. (1910): The Toxorhynchites splendens Larvae were predators of number of mosquito larvae. Res. Indian, Mus, 5:187-190.

21. Rawlins, S.C.; Clark, G.G; and Martinez, R. (1991): Effects of single introduction of Toxorh ynchites moctezuma upon Aedes aegypti on Acaribbean island J. Am. Mosq. Control Assoc. vol. 7, no. 1: 7-10
22. Richard, A. G. ( 1938): Mosquitoes and mosquito control on long Island, New York, with particular reference to the marsh problem. Bull. N. Y.st. Mus. 316: 85- 180.

23. Rosen, L. (1981): The use of Toxorhynchites mosquitoes to detect and propagate dengue and other arboviruses. Amer. J. Trop. Med. Hyogo, 30:177.

24. Terzian, L.A. and Stahler, N (1949): The effects of larval popul ation density on some laboratory characteristics of Anopheles quadri maculatus.J. Parasital. 35: 487-98.

25. Trpis M. (1972):

Development and predatory

behavior of Toxorh -ynchites brevipalpis (Diptera: Culicidae) in relation to temperature Environ. Entomol 1:537-46.

26. Ward, J. (1962): Effect of kcl and dolometric limestone on growth and ion uptake of sweet Soil. Sci, 89:347-352.

27. World Health organization (1995): Vector control for malaria and other mosquito - borne diseases: report of a who study group. Technical report series 857 . Geneva Switzerland

28. Yasuno, M. and Tonn, R.J (1970): Bionomics of Toxorhy nchites splendens in the larval habitats of Aedes aegypti. In Bangkok, Thailand. Bull . WHO 43: 762-66 
Hanaa I.Mahmoud 
Effect of Some Environmental Factors 
Hanaa I.Mahmoud 
Effect of Some Environmental Factors 


\section{Hanaa I.Mahmoud}

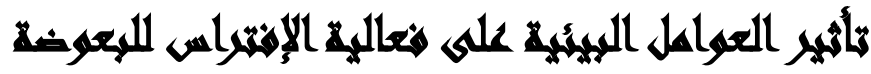

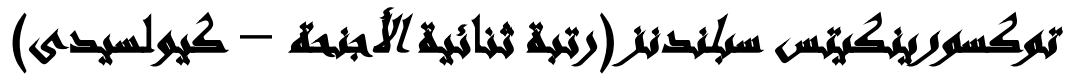 \\ د/ هناء ابراهيم محمود محمد}

كلية العلوم جامعة الازهر قسم علم الحيوان فرع بنات

يبحث هذا العمل الظروف المثلى لإستخدام البعوض توكسورينكيتس سبلندنز كوسيلة للمكافجة الحيوية لغيرها من ناقلات الأمراض من الأنواع الأخرى للبعوض.

وجد أن فعالية الإفتراس ليرقات البعوض توكسورينكيتس سبلندنن تزيد بزيادة درجات الحرارة من 30 ه- 35 م تستهلك اليرقات المفترسة عدد أكبر من الكيولكس بيبنز و الأيدس كسبيس عن يرقات أنوفليس فرعون و تتم عملية الإفتراس ليرقات توكسورينكيتس تقريباً بنفس المستوي في كل درجات الملوحة.

و من جهة أخرى وجد أن الضوء له تأثيرضئيل علي يرقات بعوض توكسورينكيتس من حيث الاغتذاء حيث أن فعالية

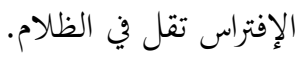

أيضاً وجد أن التزاحم ليس له تأثير على عملية الإفتراس وقد لوحظ عدم وجود وفيات أو ظهور أمراض طبيعية بين يرقات الحشرات المختبرة أثناء فترات الإختبار . وهذه الظاهرة توضح أن هذه الحشرات تفضل العيش فن بحتمعات عالية التزاحم. و تستطيع يرقات توكسورينكيتس أن تعيش حياة طبيعية ف كل من المياه العكرة والمياه المقطرة ولكنها تموت إذا وضعت فن مياه ملوثة(مياه محارى). وأن أكبر عدد من يرقات الفرائس تلتهم بواسطة يرقات توكسورينكيتس - كل

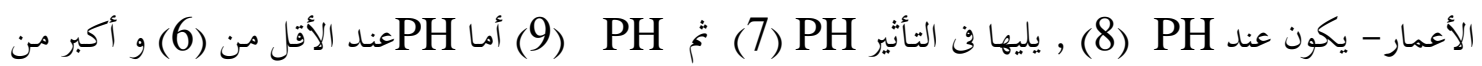
(11) فقد وجد أن لها تأثير سئ على النشاط الإفتراسى لنفس اليرقات.

وتزداد فعالية الإفتراس فن الماء تدريياً من عمق 40سم إلى 15سم, وقد لوحظ أن يرقات التوكسورينكيتس تقتنص الفريسة إما على سطح الإناء أو فن القاع · 